\title{
Development of Physics Comics Through Android- Assisted Benthik Game with Discovery Learning Model on Parabolic Motion
}

\author{
Anissa Maghfiroh ${ }^{1},{ }^{*}$ Heru Kuswanto ${ }^{2}$ \\ ${ }^{1}$ Physics Education, Graduate School, Universitas Negeri Yogyakarta, Jalan Colombo No. 1, Yogyakarta 55281, \\ Indonesia \\ ${ }^{2}$ Science Education, Graduate School, Universitas Negeri Yogyakarta, Jalan Colombo No. 1, Yogyakarta \\ 55281, Indonesia \\ *Corresponding author. Email: anissamaghfiroh@gmail.com
}

\begin{abstract}
This study aims to (1) produce physics comics learning media through andorid-assisted benthik games with discovery learning models on parabolic motion (Kofie GeBoL) and (2) determine the feasibility value of physics comic learning media through andorid-assisted benthik games with discovery learning models on parabolic motion (Kofie GeBoL). This type of research is research and development. This research uses the 4D model. This model consists of four steps; (1) Define, (2) Design, (3) Development, and (4) Disseminate. The research subject used were 30 senior high school students, who were selected by cluster sampling technique. The appropriateness of the instrument was calculated using an ideal standard deviation analysis ( $\mathrm{SBi}$ ) through the assessment of expert lecturers, teachers, and peers. The results of this research and development are (1) Kofie GeBoL learning media (2) the developed media has a very good feasibility value. Based on this finding, shows that the Kofie GeBoL media is suitable for use in learning.
\end{abstract}

Keywords: physics comic; android, Kofie GeBoL, benthik games, discovery learning.

\section{INTRODUCTION}

The development of the world today has entered the revolution era 4.0. Where information technology is currently used as a basic need in human life. In today's developing industry, human resource capabilities are needed, including critical thinking, systemic, lateral, and high level (Kemenristekdikti, 2018). In Indonesia the impact of the industrial revolution 4.0 on the world of education, the start of the digitalization of the education system that is able to adapt to change, followed by both educators and students.

Physics, a knowledge that is general in the form of theories, laws, rules, principles, which can be relied upon. As a science, physics is used as a basis for technological development, so that theories of physics require high accuracy in learning it.The abstract concept of physics causes students to have difficulty in understanding physics material [1] [2]. The problem in learning physics is learning that tends to only sharpen aspects of remembering and understanding, causing students to be passive and have limited thinking power so that it inhibits the development of their thinking [3]. Less varied and contextual physics learning also causes student learning outcomes in learning physics are still low [4] [5]. Therefore, it is needed an innovative learning media in schools based on information technology that stimulates students in learning physics concepts.

Comics are visual media to express ideas through images and combined with text for information. The implementation of digital comics has a positive impact on students, besides being interesting they also become motivated in learning[6] - [8]. Digital comics provide clear direction related to the learning process, in addition to the current era students access media not only through personal computers (PCs) but through cellphones such as the iPad, netbook, or smartphone[9]. 
Indigenous people have a relationship with the lives of students, so they can provide direct or contextual experience for them. Learning by combining technology, science, and culture makes science education more inclusive, by taking advantage of the relevance of curriculum and culture [10][11]. Indigenous-based learning is quite effective in increasing students' competence [12].

Discovery learning model is effective in learning. Learning with discovery learning models help students understand the subject matter. This model is very important because it can increase learning motivation and student learning outcomes [13]. This research focuses on the problem of developing indigenous-based physics comics learning media, as well as the use of android mobile devices.

\section{RESEARCH METHOD}

\subsection{Types of Research}

This research is a research and development (R\&D) intended to develop a product that is physics' comic learning media through Androidassisted benthik games with a discovery learning model of parabolic motion. This development research uses the stages that Thiagarajan \& Sammel (1974) covered four steps of the 4-D model, namely: (1) define, (2) design, (3) develop, and (3) disseminate [11]. The research subjects used were 30 students, who were selected by cluster sampling technique.

Stages of research with this model are (1) Define aims to analyze the needs in learning. (2) Design by starting to design products to be developed in accordance with the results of the needs analysis in learning. (3) Develop is the manufacture and development of products in accordance with the design. (4) Disseminate is the stage of using a product that has been developed. Product evaluation based on comments and suggestions for filling out questionnaires by practitioners after using the developed product.

Data collection methods use validation sheets of expert lecturers, teachers, peers, and student questionnaire responses. Validation sheets are used to obtain expert judgment. The questionnaire response sheet is used to obtain an assessment from the respondent. This data collection method is used to obtain data on the use of physics comic media through Android-assisted benthik games with the discovery learning model of parabolic motion (Kofie GeBoL).

\subsection{Instrument}

The data collection in this study uses non-test instruments. Non-test instruments in the form of product evaluation validation sheets, student questionnaire responses, and assessment sheets between friends, on the three aspects of the assessment, namely asctual system usage, uses, and attitude. This instrument is used to determine the feasibility of a product in the form of a physics comic learning medium through Android-assisted benthik games with a discovery learning model of parabolic motion material (Kofie GeBoL) on android. Assessment uses a scale of 4 according to rubric. Before the distribution of the assessment sheets and questionnaire responses were validated by experts.

\subsection{Data Analysis}

The type of data to be obtained in this study is quantitative data. Quantitative data were obtained from the assessment of product eligibility and student questionnaire responses.

Quantitative data analysis techniques performed quantitatively are used to determine the results of product validation. Data analysis obtained from several experts was carried out using the average ideal score $(\mathrm{Xi})$ and standard deviation (SBi).

$$
\begin{aligned}
X_{i} & =\frac{\text { ideal maximum score }+ \text { ideal minimum score }}{2} \\
S B_{i} & =\frac{\text { ideal maximum score }+ \text { ideal minimum score }}{6}
\end{aligned}
$$

Table 1. Convert Scores into Categories

\begin{tabular}{|c|c|}
\hline Average Score Range & Quality Category \\
\hline $\mathrm{X} \geq \mathrm{Xi}+1,8 \mathrm{SBi}$ & Very good \\
\hline $\mathrm{Xi}+0.6 \mathrm{SBi} \leq \mathrm{X} \leq \mathrm{Xi}+1.8 \mathrm{SBi}$ & Well \\
\hline $\mathrm{Xi}+1.8 \mathrm{SBi} \leq \mathrm{X} \leq \mathrm{X} 1+0.6 \mathrm{SBSi}$ & Not good \\
\hline$<\mathrm{Xi}-0.6 \mathrm{SBi}$ & Very bad \\
\hline
\end{tabular}

\section{RESULTS AND DISCUSSION}

The results at the analysis stage, obtained problems in learning physics, including learning media that are less varied, and delivery of less contextual material [5] [9]. The results were obtained through interviews with several physics teachers in Sleman district high school. Problem analysis is used as a concept analysis to compile, establish and systematically identify concepts that will be taught and developed in the development of android comics.

The results at the design stage, obtained a media design to overcome problems in learning physics. Media formphysics comic media through Androidassisted benthik games with discovery learning 
models of parabolic motion (Kofie GeBoL) is expected to overcome these problems. The initial stage of making comics by creating a draft story line that can stimulate students to think critically. Then the drawing stage for the comic begins with sketches on paper. Comic drawings created by drawing, coloring and filling in dialog text using the Corel Draw 2017.

The ready-made images with the extension .jpg are compiled into comics with the help of the Sigil application [14]. Comic files with the .EPUB extension can be opened on android smartphones, where the Android smartphone already has the Reasily EPUB or EPUB Reader application.

Android-based physics comics designed for the Android operating system with the following minimum specifications: (1) file size no more than

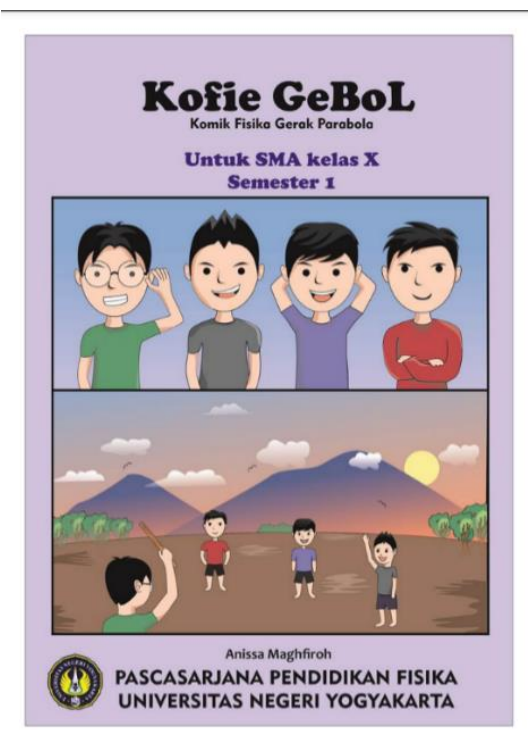

Figure 1. Performance Part of Kofie Gebol Menu

The Kofie GeBoL media is assisted with android, then assessed by experts to get improvements. The product improvement results are then developed to be tested on students (development). The implementation phase, carried out by implementing the product in learning physics at school, aims to determine the response of students to the media developed. Students' responses to the use of the developed product can be seen from filling in the response questionnaire as an evaluation material. The results of Kofie GeBoL's media assessment were obtained from the assessment of expert lecturers, teachers, peers and student questionnaire responses.

The results of the physics comics media product assessment through Android-assisted benthik games are presented in Table 2.

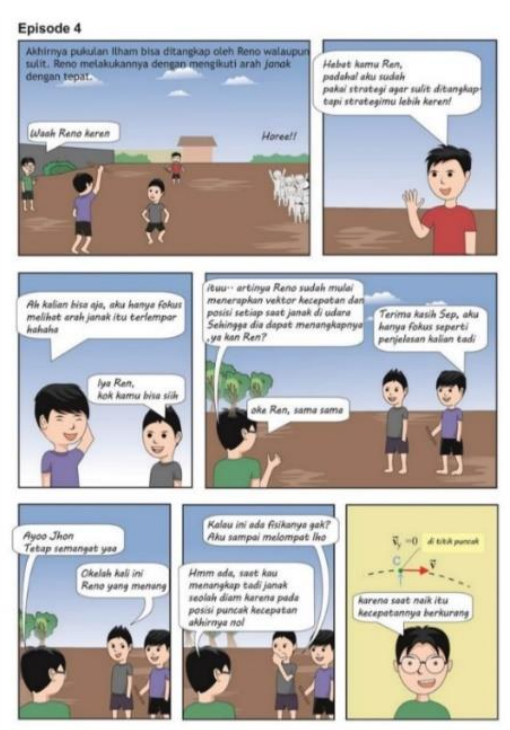

250MB, (2) minimum 512MB ram, (3) minimum Android version of ICS (Ice Cream Sandwich), and (4) screen of at least $240 \times 320$ pixels. The storyline that is packaged in a comic consists of four Indonesian-language episodes that tell a group of teenagers in the countryside, where when they come home from school playing benthik. Benthik game whose trajectory is analyzed with the physics concept of parabolic motion material. The compilation of stories in this comic uses discovery learning model, where the story is about the player finding problems in benthik games and solving these problems logically according to the concept of parabolic motion. Comics with full color images and clear font fonts are expected to attract learning interest from readers. Figure 1 shows the comic display inside the smartphone. 


\begin{tabular}{|l|l|l|l|}
\hline 8 & Picture & 3.94 & Very good \\
\hline 9 & Ease of Use & 3.81 & Very good \\
\hline \multicolumn{2}{|c|}{ Average } & 3.81 & Very good \\
\hline
\end{tabular}

The results of the assessment by experts on the feasibility of the developed comic media products, obtained an average of 3.81 included in the excellent category. Thus the comics developed are suitable for use in learning physics. In the material aspects of learning values and materials and exercises have the same value of 3.75 , while in the aspect of media the value of feasibility has the lowest value of 3.67 this is because physics comics through indigenous benthik games only contain parabolic motion which is limited to the trajectory of motion. The results of the assessment of responses by students to the learning media used are shown in Table 3.

Table 3. Student Assessment Results

\begin{tabular}{|c|l|c|c|}
\hline No. & Aspect & $\begin{array}{c}\text { Rating } \\
\text { result }\end{array}$ & Category \\
\hline 1 & $\begin{array}{l}\text { Perceived ease } \\
\text { of use }\end{array}$ & 3.88 & Very good \\
\hline 2 & $\begin{array}{l}\text { Perceived } \\
\text { benefits }\end{array}$ & 3.75 & Very good \\
\hline 3 & Product appeal & 3.88 & Very good \\
\hline 4 & $\begin{array}{l}\text { Use of actual } \\
\text { products }\end{array}$ & 3.88 & Very good \\
\hline \multicolumn{2}{|l}{ Average } & $\mathbf{3 . 8 4}$ & Very good \\
\hline
\end{tabular}

The results of the assessment of students' responses to the media developed namely physics comics obtained an average of 3.84 which is included in the excellent category. Thus, the product as a learning device in the form of physics comic media through Android-assisted benthik games is feasible to use. In the aspect of perceived benefits the lowest value is obtained, this is because comics cannot be applied to all physical material.

The results of product development in the form of physics comics can overcome the problems of learning physics. Physics learning becomes more contextual, interesting and varied [15] [16]. Learning physics by using comics can also improve students' literacy and thinking abilities [17] - [20].

\section{CONCLUSION}

The results of research and development are produced physics comics learning media through Android-assisted benthik games with discovery learning models on parabolic motion. The assessment of physics comic media through indigenous Android-assisted benthik games with discovery learning models on parabolic motion is carried out by expert lecturers, teachers and peers having a very good feasibility value. This shows that the physics comic media through Android-assisted benthik games with the discovery learning model on parabolic motion developed which is feasible to be used as a learning medium.

\section{REFERENCES}

[1] Handayani DP, Jumadi, Wilujeng I, and Kuswanto H 2019 J. Phys. Conf. Ser Development of Comic Integrated Student Worksheet to Improve Critical Thinking Ability in Microscope Material 1233012069. https://doi.org/10.1088/17426596/1233/1/012069

[2] Haroky F, Nikmah S, Wilujeng I, Jumadi, and Kuswanto H 2019 IOP Conf. Series: Journal of Physics: Conf. Android Assisted Physics Comic Learning to Train Students' Series Conceptual Understanding of Newton's Gravity 1233012045.

https://doi.org/10.1088/17426596/1233/1/012045

[3] Syalehin, M Rahmad, Sri Hartini, and Sur Habit 2015 Scientific Periodical Education Physics Development Student Activity Sheet Based on Critical Thinking Skills to Support the Implementation of 2013 Curriculum 3 52-9.

[4] Hadi WS and Dwijananti P 2015 Unnes Physics Education Journal Development of Android-Based Physics Comics as a Principal Supplement for Radioactivity for High Schools 2252-6935. http://dx.doi.org/10.1089/ars.2015.6320

[5] Rani SA, Wiyatmo Y, and Kuswanto H 2017 Indonesian Journal of Natural Sciences Education Concept Attainment Worksheet to Enhance Concept Knowledge and Science Process Skills in Physics Instruction 6 32634. https://doi.org/10.15294/jpii.v6i2.10520

[6] Ntobuo, NE, Arbie, A., \& Amali, LN 2018 The Development of Gravity Comic Learning Media Based on Gorontalo Culture, J. Educators. Indonesian Natural Sciences, 7: 246-251.

https://journal.unnes.ac.id/nju/index.php/jpii /article/view/14344/7900

[7] Lesmono, AD, Bachtiar, RW, \& Muzdalifah, A. (2018). The Instructional-Based AndroWeb Comic on Work and Energy Topic for Senior High School Students, J. Educators. Indonesian Natural Sciences, 7: 147-153. https://doi.org/10.15294/jpii.v7i2.14245 
[8] Hartini, S., Firdausi, S., \& Sulaeman, NF 2018 The Development of Physics Teaching Materials Based on Local Wisdom to Train Saraba Kawa Characters, J. Educators. Indonesian Natural Sciences, 7: 130-137. https://doi.org/10.15294/jpii.v7i2

[9] Lee, YC 2017 When technology, science and culture meet: insights from ancient Chinese technology, Cult. Stud Sci Educ. https://doi.org/10.1007/s11422-017-9805-5

[10] Güney, BG 2012 The Use of History of Science as a Cultural Tool to Promote Students' Empathy with the Culture of Science, 12: 533-539.

https://files.eric.ed.gov/fulltext/EJ978457.pd f

[11] Mungmachon, R. 2012 Knowledge and Local Wisdom: Community Treasure Miss Roikhwanphut Mungmachon PhD Candidate in Integral Development Studies, Int. J. Humanit. Soc. Sci., 2: 174-181.

http://www.ijhssnet.com/journals/Vol_2_No 13_July_2012/18.pdf

[12] Bamiro, AO 2015 Effects of guided discovery and think-pair-share strategies on secondary school students' achievement in chemistry, SAGE Open, 5: 1-7. https://doi.org/10.1177/2158244014564754

[13] Collete, AT, \& Chiappetta, EL 1994 Science Instruction in the Middle and Secondary Schools, Thiird Edi. United States of America.

[14] Darma RS, A. Setyadi A, and Wilujeng I 2019 J. Phys .: Conf. Ser. Multimedia Learning Module Development based on SIGIL Software in Physics Learning 1233 012042. https://doi.org/10.1088/17426596/1233/1/012042

[15] Mulyani, N. 2016 Super Fun Traditional Indonesian Children Game. Yogyakarta: Diva Press.

[16] Liliarti N and Kuswanto H 2018 Int. J. Instr. Improving the Competence of Diagrammatic and Argumentative Representation in Physics through Android-based Mobile Learning Application 11 1308-1470. https://doi.org/10.12973/iji.2018.1138a

[17] Handayani, DP, Jumadi, Wilujeng, I., \& Kuswanto, H. 2019 Development of Comic Integrated Student Worksheet to Improve Critical Thinking Ability in Microscope Materials, "J. Phys. Conf. Ser., 1233: 012069. https://doi.org/10.1088/17426596/1233/1/012069
[18] Sari FP, Ratnaningtyas, Wilujeng I, Jumadi, and Kuswanto H 2019 J. Phys. Conf. Ser. Development of Android Comics media on Thermodynamic Experiment to Map the Science Process Skill for Senior High School 1233012052.

https://doi.org/10.1088/1742-

6596/1233/1/012052

[19] Haroky F, Nikmah S, Wilujeng I, Jumadi, and Kuswanto H 2019 Physics: Conf. Series Android Assisted Physics Comic Learning to Train Students' Conceptual Understanding of Newton's Gravity 1233012045.

https://doi.org/10.1088/17426596/1233/1/012045

[20] Ratnaningtyas L, Wilujeng I, and Kuswanto H 2019 Journal of Physics: Conference Series Android-based Physics Comic Media Development on Thermodynamic Experiment for Mapping Cooperate Attitude for Senior High School Android-based Physics Comic Media Development on Thermodynamic Experiment for Mapping Cooperate Attitude for Senior High School 1233012054.

https://doi.org/10.1088/17426596/1233/1/012054 